\title{
VEGETATION STRUCTURE AND LITHOLOGY RESPONSE TO THE PALEOCENE-EOCENE THERMAL MAXIMUM IN THE HANNA BASIN, WYOMING
}

KEIFER NACE, Whitman College

Research Advisor: Pat Spencer

\section{INTRODUCTION}

The Paleocene-Eocene Thermal Maximum (PETM), a rapid global warming event $\sim 56$ million years ago caused by a large release of isotopically-light carbon into earth's atmosphere and oceans, provides geologic parallels to anthropogenic climate change. Thousands of petagrams of carbon were released in less than $20 \mathrm{ka}$, causing a global negative carbon isotopic excursion (CIE), ocean acidification, a 5-8 $\mathrm{C}$ increase in global temperatures, and at least a doubling of atmospheric CO2 levels (McInerney \& Wing, 2011). In midlatitude continental interiors, increased temperatures led to lower mean annual rainfall, causing more seasonally dry conditions and increased water stress (Kraus et al., 2015). PETM sandstones in both the Bighorn and Piceance Creek Basin record changes in fluvial systems, likely caused by changes in sediment flux, increased variability of precipitation, reductions in vegetation cover, or some combination of these (Foreman et al., 2012; Foreman, 2014). Few extinctions occurred during the PETM, but terrestrial and marine organisms experienced major shifts in geographic ranges, changes in food sources, and rapid evolution (McInerney \& Wing, 2011). The best record of plant responses to PETM environmental change to date comes from the Bighorn Basin in northwestern Wyoming. Wing et al. (2005) demonstrated a decrease in leaf size, reflecting an increase in water stress. Taxonomic analyses showed a distinct difference in flora composition during the PETM versus directly before or after (Wing \& Currano, 2013). Conifers and a combination of deciduous and evergreen broadleaved families were the primary pre- and post-PETM megafloras; PETM megafloras lack conifers but were abundant in the dry-tolerant Fabaceae family (Wing et al. 2005; Wing \& Currano, 2013; Smith et al. 2007). During the CIE recovery, many typical Paleocene plants returned, implying that the plant populations were able to migrate to refugia during the Thermal Maximum (Wing \& Currano, 2013).

Paleobotanic and sedimentologic studies have documented taxonomic turnover as well as hypothesized that vegetation cover decreased during the PETM. Here, we use Leaf Area Index [LAI = foliage area (m2) / ground area (m2)] to quantitatively reconstruct, for the first time, vegetation structure before, during, and after the PETM. Vegetation structure, the three-dimensional architecture of a plant community, is crucial to ecosystems, impacting fluvial systems, soil temperature and moisture, erosion, plant and animal compositions, and the hydrologic and carbon cycles (Dunn, et al., 2015). Modern LAI values range from 0 (open canopy) to 6 (dense canopy) (Dunn et al., 2015). Reconstructed LAI (rLAI) modeling is based on the sun's impact on the leaf epidermis. In shaded environments, epidermal cells are larger, more elliptical, and have more undulatory cell walls than cells exposed to the sun. Since vegetation structure is directly related to light, larger, more elliptical, and more undulatory cells are likely to be associated with a dense canopy rather than with an open forest. A relationship between the morphology of leaf epidermal cells and LAI was first established using phytoliths (Dunn et al. 2015), and later expanded to use fossil cuticle, which is preserved in depositional environments that do not preserve phytoliths (Dunn et al., personal communication). A modern calibration set of Costa Rican soils collected from a wide range of LAI conditions was used to 
establish these relationships (Dunn et al. 2015).

\section{GEOLOGIC SETTING}

The Hanna Basin, located in south-central Wyoming, is a Laramide basin with a high sedimentation rate, preserving a thick sequence of Cretaceous to Eocene sedimentary strata (Gill et al., 1970). The Hanna Formation, made up of alternating drape coal beds, bodies of carbonaceous shale and mudstone, and sand bodies, contains the Paleocene-Eocene boundary. The basin serves as an important record of the vegetation and fluvial systems in a generally humid environment, compared to the well-studied, seasonally dry Bighorn Basin. Since the Hanna Basin was at midlatitude, in the continental interior, it is possible that it endured similar effects of the PETM as the Bighorn Basin and in the Piceance Creek Basin, including a warmer, seasonally dryer climate with increased monsoonal precipitation. We hypothesize that the Hanna Basin will show a less dense vegetation structure (lower LAI value) during the PETM than before and after, due to a drier climate and increased water stress on plants.

\section{METHODS}

Bed by bed descriptions of grain size, grain shape, sedimentary structures, color, clay content, and organic matter were recorded. Sections and bed thicknesses were measured using a Jacob's staff. During the PETM, there is a significant lithological change from predominantly fine-grained sediments to laterally extensive, multistory sandstone beds (Dechesne et al., in review). Therefore, in order to isolate the effects of lithological and PETM climate changes on vegetation structure, sections were chosen before and after the PETM that include large sandstone beds. The pre-PETM section includes a large, laterally extensive sheet sand, and the postPETM section includes both a smaller, lenticular channel and a large, laterally extensive sheet sand.

Samples of fine-grained, organic-rich rocks were collected from the three sections for LAI analysis. Four samples were analyzed from the pre-PETM section, and ten samples were analyzed from the postPETM section. Nineteen samples, 16 of which occur within the negative carbon isotope excursion, were collected and analyzed for the PETM section between 2016-2018 (Dunn et al., 2018). To isolate leaf cuticles from the matrix, fragments of the collected rock samples were sent to Global Geolabs for palynological processing. Leaf cuticles were examined through a Leica compound light microscope and photos of the cuticles were taken with a Vernier camera at 40x magnification. The photographed cuticles were traced using a Wacom tablet and morphometric measurements were made using ImageJ. Seventyfive photos were taken and about 300 epidermal cells were traced and measured for each sample. LAI was quantified using Dunn et al.'s (2018) cuticle calibration dataset and the following relationship includes aspect ratio ( $\mathrm{AR}=$ major $/$ minor axis $)$ and undulation index (UI = epidermal cell circumference / circumference of the circle with the same area as the cell)

$\mathrm{rLAI}=4.05($ mean UI $)+15.32($ mean $\mathrm{AR})-25.38$ Eq. 1

Fresh, organic-rich rock samples, exposed through trenching, were collected for carbon isotope analyses. Six samples were taken from the pre-PETM, 155 samples from the PETM, and 32 samples from the post-PETM sections. The preparation process for bulk organic carbon isotope $\left(\delta^{13} \mathrm{C}\right)$ measurements included powdering samples using a mortar and pestle, treating samples in two $\mathrm{HCl}$ baths to dissolve all carbonates, and weighing dry samples into tin capsules, as in Aziz et al. (2008) and Baczynski et al. (2013; 2016). The total organic carbon (TOC) and the carbon isotopic values were measured at UC Davis Stable Isotope Facility using an elemental analyzer (Elementar Vario EL Cube) interfaced to a continuous flow isotope ratio mass spectrometer (PDZ Europa 20-20). Precision/ accuracy was assessed using internal standards and all data were reported in standard delta-notation relative to VPDB.

\section{RESULTS}

Fig. 1 presents stratigraphically related lithology, rLAI, and $\delta^{13} \mathrm{C}$ values before the PETM. The first 38 meters of section preserve interbedded meandering sandstone channel sequences, shales, and mudstones. At 38 meters in the section, a large, 47-meter-thick 


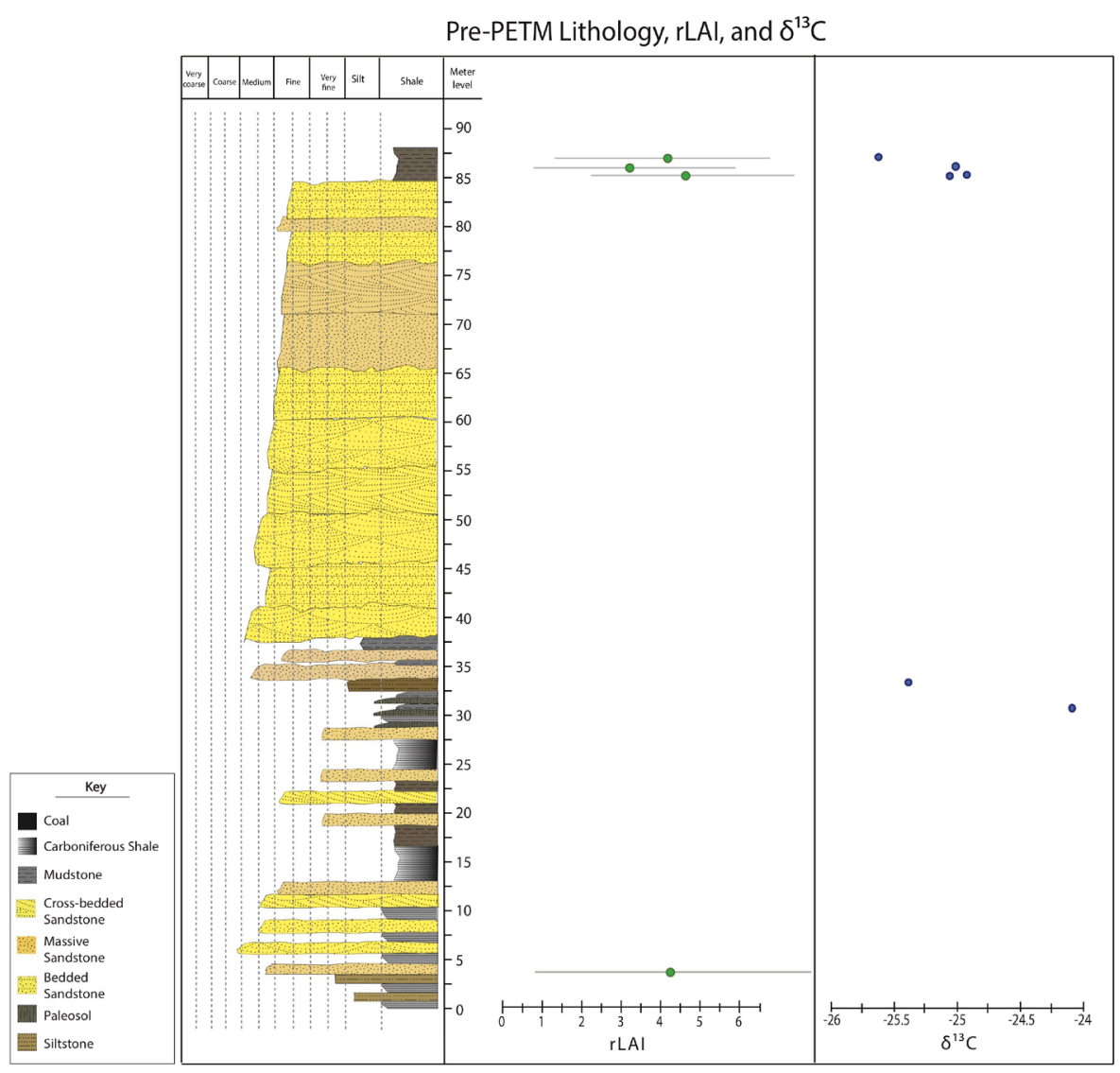

Figure 1. Pre-PETM lithology, rLAI, and $\delta^{13} \mathrm{C}$ values.

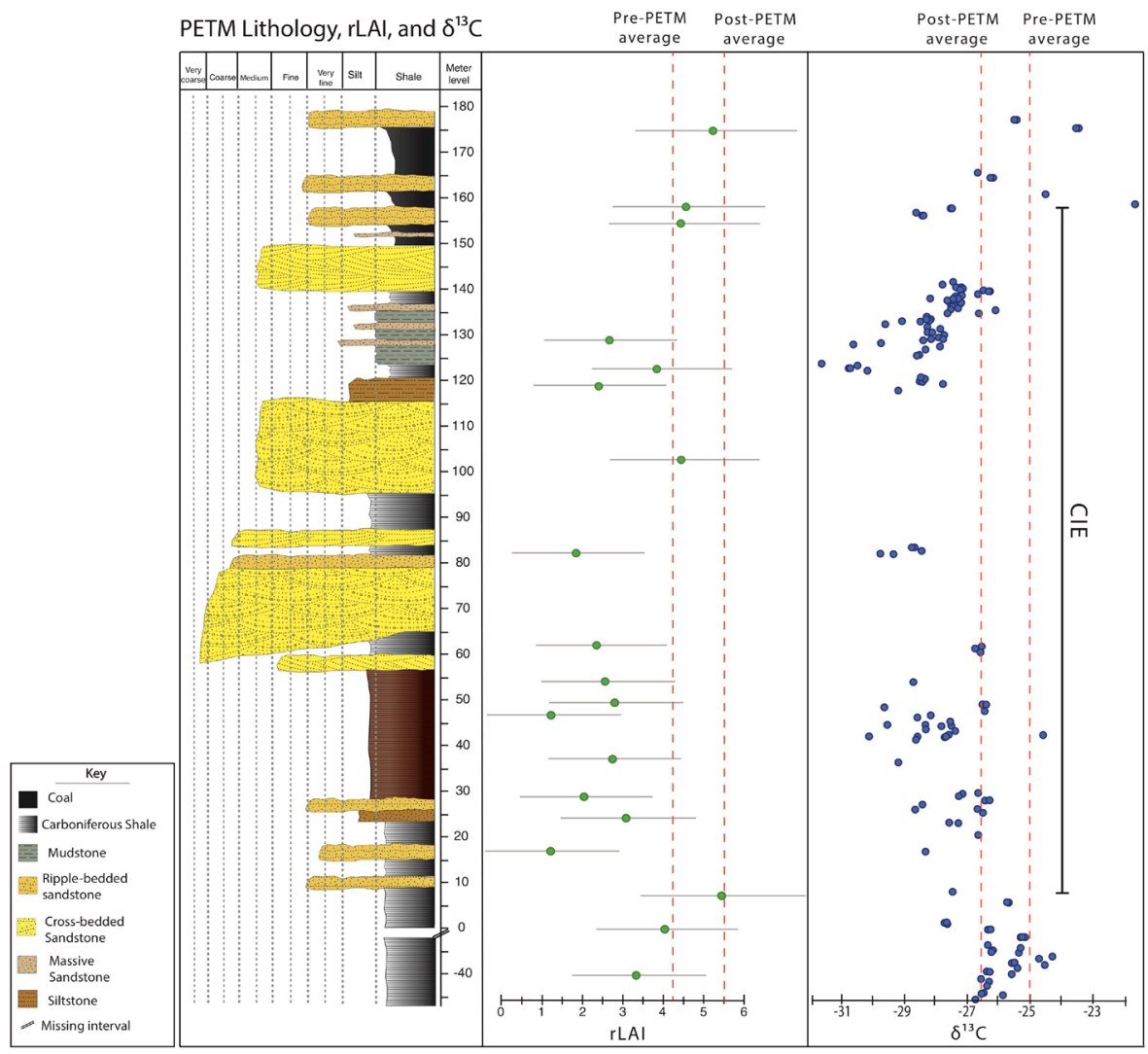

Figure 2. PETM lithology, rLAI, and $\delta^{13} C$ values. Pre- and Post-PETM rLAI and $\delta^{13} C$ averaged values are indicated by the red dotted lines, and the CIE is marked by the black line. 


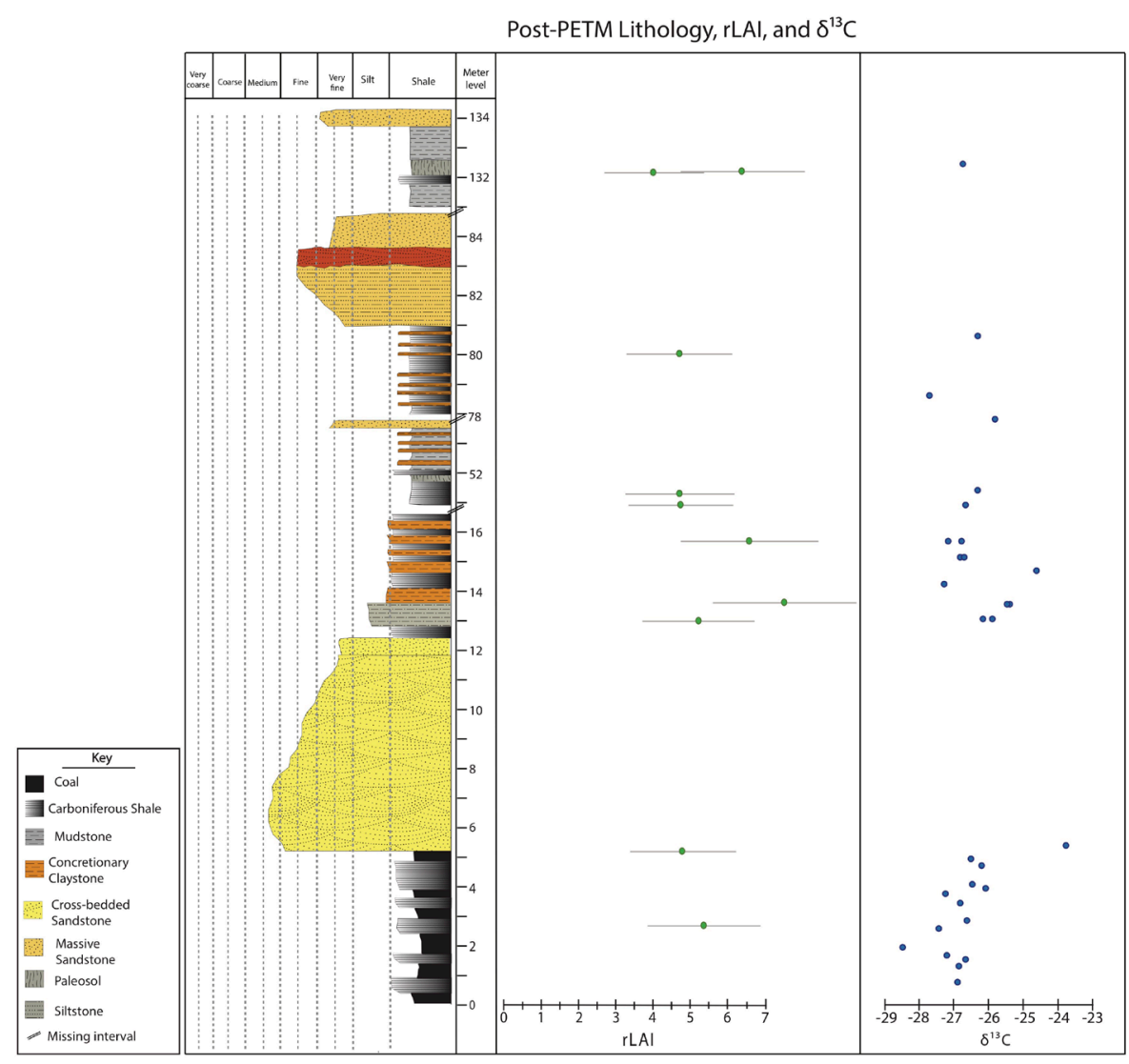

Figure 3. Post-PETM lithology, rLAI, and $\delta^{13} C$ values

bedded sheet sandstone is present, followed by mudstone to the top of the section. rLAI values ranged from 3.9 to 4.6, with an average value of $4.2 \pm 2.0$. $\delta^{13} \mathrm{C}$ values averaged $-25.03 \%$ with a narrow range from $-25.60 \%$ to $-24.18 \%$ ( $1.42 \%$ range). TOC also displayed a narrow range from $7.4 \%$ to $11.4 \%$ ( $4 \%$ range) with a mean value of $9.39 \%$.

Lithology, rLAI, and $\delta^{13} \mathrm{C}$ values from the PETM section are presented in Figure 2. The first 60 meters of this section is primarily carbonaceous shale. At 10 meters, $\delta^{13} \mathrm{C}$ decreases marking the onset of the CIE, and the lowest rLAI value (1.2) occurs at 16.5 meters. In the middle of the CIE, at 65 meters, a 17-meterthick coarse-grained, braided channel sequence is deposited, followed by interbedded shale and sand deposits (Semeraro et al., 2019). A second, 21 -meterthick braided channel is present at 96 meters, and 23 meters of fine-grain deposits of siltstone, shale, and mudstone come after. At 140 meters, a third coarsegrained braided channel accumulated over 11 meters. Fine-grained sands interbedded with coal complete the section at 178 meters, with the CIE terminating at 157 meters. During the CIE, the mean rLAI value was $3.0 \pm 1.9$, with a range from 1.2 to 4.6 . Bulk organic carbon isotope values during the CIE displayed a range from $-31.83 \%$ to -24.76 (7.07\%o range) with an average of $-28.08 \%$. TOC show a large range from $0.11 \%$ to $36.74 \%$ (36.36\% range) with a mean value of $1.04 \%$.

The base of the post-PETM section is dominated by interbedded coals and carbonaceous shales (Fig. $3)$. At meter five in the section, a seven-meter-thick lenticular sand channel coarsens upwards and is bounded by a carbonaceous shale and concretionary claystone sequence. The missing interval break in the stratigraphic section between 16.6 meters and 51.1 meters is dominated by a similar shale and claystone sequence. Between 51.1 and 54 meters, the lithology is dominated by a mudstone and concretionary claystone sequence and is capped by a small, very fine-grained sandstone bed. After the sandstone, within the missing interval and through to 81 meters in the section, the lithology consists of the shale and concretionary claystone sequence. The last shale bed grades into a siltstone and then to a cross-bedded sandstone at 85 meters. Between 85 and 130 meters, a 45-meter-thick sheet sandstone is present, followed by mudstone dominated lithology. Post-PETM, rLAI values range 


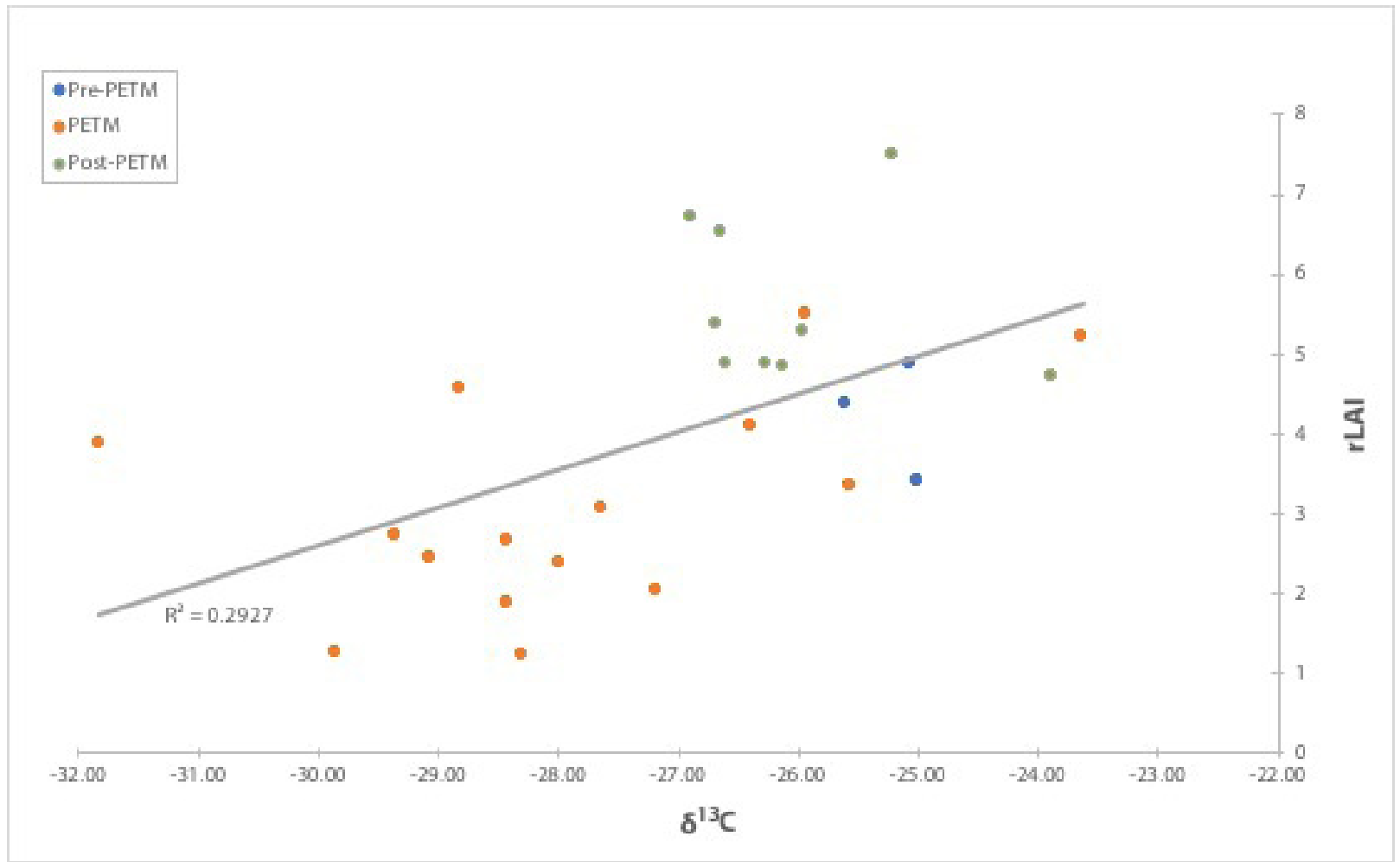

Figure 4. Correlation of rLAI and $\delta^{13} C$ values

from 4.1 to 7.5 with a mean value of $5.5 \pm 2.0$. $\delta^{13} \mathrm{C}$ values average to be $-26.7 \%$, and ranged from $-28.56 \%$ o to $-23.89 \%$ o (4.67\%o range). TOC values demonstrate a wide range from $0.51 \%$ to $66.24 \%$ $(65.73 \%$ range) with a mean value of $16.07 \%$.

Figure 4 illustrates the correlation between rLAI and $\delta^{13} \mathrm{C}$, showing that the more negative $\delta^{13} \mathrm{C}$ values relate to lower rLAI values; however, this relationship is weak $(\mathrm{R} 2=0.29)$. No relationship is present between TOC and rLAI.

\section{DISCUSSION}

Prior to the PETM, our section demonstrates a meandering fluvial system, with floodplain deposits of shales and mudstones interbedded with thin sandstone splays. The 47-meter-thick sandstone within the section represents a meandering point bar lateral accretion and is followed by flood plain deposits. Meandering rivers systems require bank strength, often stabilized by vegetation (Braudrick et al., 2009; Schumm, 1985), and rLAI values of 3.9 to 4.6 provide evidence for vegetated bank stabilization. Our post-PETM section preserves a swampy, densely forested environment, as indicated by abundant coals and carbonaceous shales and the highest rLAI values in our dataset. Swamp facies are occasionally interrupted by sand deposits. The post-PETM section transitions back to a meandering system as indicated by the 45-meter-thick, laterally extensive sandstone with fine floodplain deposits. The meandering channel sequences pre- and post- do not cause a decrease in rLAI within the PETM, but the elevated values combined with the meandering channels indicate stable, vegetated banks prior to and after the recovery of the PETM.

The PETM caused significant changes to vegetation structure and fluvial systems within the Hanna Basin. During the CIE, rLAI values decreased (average rLAI $=3.0$ ), indicating a more open canopy environment in contrast to before (4.2) and after (5.5). Importantly, the decrease in rLAI occurs before the first laterally extensive channel, suggesting that the reduction in rLAI was a result of climate change rather than a change of fluvial systems. Other PETM sites within continental interiors show a decrease in mean annual precipitation (Kraus et al., 2015) or increased monsoonal precipitation (Forman et al. 2012), both of which can significantly affect vegetation. During periods with higher temperatures, seasonal changes 
in precipitation led to water stress, changes in phenology, and decreased biomass. The effects of extreme precipitation in mesic sites led to a decrease in soil water content and above-ground primary productivity of plants (Zeppel et al., 2014). The shift to a potentially braided channel system after rLAI decreases may be the result of bank destabilization due to the decrease in vegetation. In addition, braided systems require high discharge and sediment loads (Tucker \& Slingerland, 1997). An increase in seasonally extreme precipitation events could account for higher discharge rates, whereas increased erosion from destabilized banks could explain increase sediment loads.

Correlation testing revealed rLAI and $\delta^{13} \mathrm{C}$ to be weakly related. Diefendorf et al. (2010) found that $\Delta$ leaf (the offset between $\delta^{13} \mathrm{Catm}$ and $\delta^{13} \mathrm{Cleaf}$ ) values in $\mathrm{C} 3$ plants decrease with reduction of water availability and with increased water-efficiency use. Furthermore, a decrease in $\Delta$ leaf values would indicate an increase in $\delta^{13} \mathrm{C}$ values, which differs from our findings. Our results indicate a decrease in $\delta^{13} \mathrm{C}$ values with a decrease in water availability. This difference in results indicates that chance may play a role in the negative carbon isotope excursion during the PETM as opposed to a positive isotope excursion. In addition, the correlation between rLAI and $\delta^{13} \mathrm{C}$ could be driven by the radical taxonomical change from a mixed angiosperm/conifer flora to an angiosperm dominated flora during the PETM (Smith et al., 2007).

\section{CONCLUSION}

In this study we evaluated the interaction of climate and fluvial system changes on vegetation structure. During the PETM, vegetation became less dense due to warmer, more seasonally dry conditions with periods of extreme precipitation. Reductions in vegetation potentially caused a shift from meandering to braided fluvial systems. Post-PETM, a swampy, densely forested environment is preserved, and eventually transitions back to a meandering fluvial system, similar to the pre-PETM environment. This reconstruction of climatic effects on vegetation and fluvial systems adds to studies conducted within midlatitude continental interiors, such as in the Bighorn Basin and Piceance Creek Basin. Further megaflora paleobotany research could add to the larger picture of vegetation and climate within the Hanna Basin. Understanding vegetation structure response to the PETM illustrates a portrait of possible modern vegetation reactions to anthropogenic climate change.

\section{ACKNOWLEDGEMENTS}

This material is based upon the work supported by the Keck Geology Consortium and the National Science Foundation Grant No. 1659322, as well as NSF grant EAR 145031 to Ellen Currano. Thank you to the project directors, Ellen Currano and Brady Foreman, for your continuous support throughout the project, and also thank you, Regan Dunn and Marieke Dechesne for sharing your expertise. My love for the field and curiosity to learn the stories of ancient landscapes has been ignited by your guidance and encouragement. I would also like to thank Pat Spencer and the Whitman College Geology department for your assistance as well as the ASWC Travel and Student Development Fund for sponsoring my flight to GSA regional meeting. Finally, thank you to James Chisholm, Xavier Nogueira, Anthony Semeraro, Christine Shonnard, and especially Jake Polsak for your great company while digging trenches, tracing cuticles, and cooking field meals.

\section{REFERENCES}

Aziz HA, Hilgen FJ, van Luijk GM, Sluijs A, Kraus MJ, et al. (2008). Astronomical climate control on paleosol stacking patterns in the upper Paleocene-lower Eocene Willwood Formation, Bighorn Basin, Wyoming. Geology, vol. 36, pp. 531-34.

Baczynski, A.A., McInerney, F.A, Wing, S.L., Kraus, M.J., Bloch, J.I., Boyer, D.M., Secord, R., Morse, P.E., \& Fricke, H.C. (2013). Chemostratigraphic implications of spatial variation in the PaleoceneEocene Thermal Maximum carbon isotope excursion, SE Bighorn Basin, Wyoming. Geochemistry, Geophysics, Geosystems, vol. 14, pp. 4133-4152. doi: https://doi.org/10.1002/ ggge. 20265

Baczynski, A.A., McInerney, F.A, Wing, S.L., Kraus, 
M.J., Morse, P.E., Bloch, J.I., Chung, A.H., \& Freeman, K.H. (2016). Distortion of carbon isotope excursion in bulk soil organic matter during the Paleocene-Eocene thermal maximum. GSA Bulletin, vol. 128, pp. 1352-1366. doi: https://doi.org/10.1130/B31389.1

Braudrick, C. A., W. E. Dietrich, G. T. Leverich, and L. S. Sklar (2009), Experimental evidence for the conditions necessary to sustain meandering in coarse bedded rivers, National Academy of Sciences, vol. 106, no. 40, pp. 16936-16941. https://www.jstor.org/stable/40485114

Dechesne, M., Currano, E.D., Dunn, R.E., Higgins, P., Hartman, J. H., Chamberlain, K.R., \& Holm-Denoma, C.S. (In review). Depositional patterns of the fluvial to paludal strata of the Hanna Formation across the Paleocene - Eocene boundary, Hanna Basin, Wyoming. Geosphere.

Diefendorf AF, Mueller KE, Wing SL, Koch PL, Freeman KH. (2010). Global patterns in leaf 13C discrimination and implications for studies of past and future climate. Proc. Natl. Acad. Sci. USA, vol. 107, pp. 5738-43.

Dunn, R.E., Currano, E.D., Dechesne, M., \& Foreman, B.Z. (2018). Forest canopy response to greenhouse warming at the Paleocene-Eocene Thermal Maximum. GSA Annual Meeting, Indianapolis.

Dunn, R.E., Strömberg C.A.E., Madden, R.H., Kohn, M.J., Carlini, A.A. (2015). Linked canopy, climate, and faunal change in the Cenozoic of Patagonia. Science, vol. 347, no. 6219, pp. 258 261.

Foreman, B.Z. (2014). Climate-driven generation of a fluvial sheet sand body at the Paleocene-Eocene boundary in north-west Wyoming (USA). Basin Research, vol. 26, pp. 25-241. doi: 10.1111/ bre.12027.

Foreman, B.Z., Heller, P.L., \& Clementz, M.T. (2012). Fluvial response to abrupt global warming at the Paleocene/Eocene boundary. Nature, vol. 491, pp. 92-95.
Gill, J.R., Merewether, E. A. \& Cobban, W. A. (1970). Stratigraphy and Nomenclature of Some Upper Cretaceous and Lower Tertiary Rocks in SouthCentral Wyoming. USGS Report. doi: 10.3133/ pp667

Kraus, M.J., Woody D.T., Smith J.J., Dukic, V. (2015). Alluvial response to the Paleocene-Eocene Thermal Maximum climatic event, Polecat Bench, Wyoming (U.S.A.). Palaeogeography, Palaeoclimatology, Palaeoecology, vol. 435, pp. 177-192.

McInernery, F.A. \& Wing, S.L. (2011). The PaleoceneEocene thermal maximum: a perturbation of carbon cycle, climate, and biosphere with implications for the future. Annu. Rev. Earth Planet. Sci., vol. 39, pp. 489-516.

Schumm, S.A. (1985). Patterns of alluvial rivers. Annu. Rev. Earth Planet Sci., vol. 13, pp. 5-27.

Semeraro, A., Currano, E.D., Foreman, B.Z. (2019). Paleocurrent variability in meandering and braided river systems: modern calibrations and stratigraphic case studies spanning the PaleoceneEocene Thermal Maximum. Proceedings of the Keck Geology Consortium, v. 32.

Smith, F.A., Wing, S.L. \& Freeman, K.H. (2007). Magnitude of the carbon isotope excursion at the Paleocene-Eocene Thermal Maximum: the role of plant community change. Earth Planet. Sci. Lett., vol. 262, pp. 50-65.

Tucker, G.E. \& Slingerlan, R. (1997). Drainage basin responses to climate change. Water Resoures Research, vol. 33, pp. 2031-2047.

Wing, S.L. \& Currano, E.D. (2013). Plant Response to Global Greenhouse Event 56 Million Years Ago. American Journal of Botany, 100 (7), 1-21. doi: 10.3732/ajb.1200554

Wing SL, Harrington GJ, Smith FA, Bloch JI, Boyer DM, Freeman KH. 2005. Transient floral change and rapid global warming at the PaleoceneEocene boundary. Science, vol. 310, pp. 993-96. 
Zeppel, M.J.B, Wilks, J.V., \& Lewis, J.D. (2014).

Impacts of extreme precipitation and

seasonal changes in precipitation on plants.

Biogeosciences, vol. 11, pp. 3083-3093. 